\title{
РИЗОМА КАК ПРИНЦИП ОРГАНИЗАЦИИ ПРЕЦЕДЕНТНЫХ ФЕНОМЕНОВ И ЛИНГВОКУЛЬТУРНЫХ КОНЦЕПТОВ
}

По образному сравнению русского ученого И. М. Снегирева, «коренные понятия», «уклоняясь от своего истока и протекая сквозь мир и человечество, заимствуют от местности, климата и духа народов различные образы. Как семена растений часто заносятся ветром на чуждую им землю, так и поверья путем преданий переходят из одной страны в другую и, там перерождаясь, принимают особенные виды и цветы» (Снегирев 2012). Под коренными понятиями, по-видимому, надо понимать архетипические, базовые, универсальные единицы, образы которых хранятся в коллективной памяти человечества. Развитие значений слов, и связанные с ним семантические процессы также характеризуются непредсказуемым выбором путей, их обрывами и неожиданным продолжением и имеет характеристики особого вида системности, а именно - ризомы ${ }^{1}$.

Как отметили Ж. Делез и Ф. Гваттари, «ризома не является ответственной ни за какую структуральную или генеративную модель. Она чужда всякой идее генетической оси в качестве глубинной структуры. Описать ризому означает составить карту. Карта открыта, она способна на связь во всех своих измерениях, демонтирована, обратима, она подвержена постояным модификациям. Она может быть разорвана, перевернута, адаптирована к любым способам сборки, над ней могут работать индивид, группа или социальная формация...» (Делез, Гваттари 1998). Вместе с тем авторы отмечают, что в ризомах существуют структуры дерева или корней, но верно и обратное - ветка дерева или сегмент корня могут начать распускаться в ризому... В сердцевине дерева, в полости корня или в изгибе ветви может образовать-

${ }^{1}$ Ризома в ботанике, откуда был заимствован термин Ж. Делезом и Ф. Гваттари, - это неструктурированная, корневищная неиерархическая система, в которой происходит постоянный обмен с окружающей средой через постоянное отмирание побегов, их обрывы и произрастание новых. 
ся новая ризома... Таким образом, генеративные деревья, построенные по синтагматической модели Хомского, могли бы раскрыться во всех направлениях, в свою очередь образовать ризому [сризомировать]. (Делез, Гваттари 1998). Принципам ризомы, по мнению авторов, подчиняется морфологическая структура человеческого мозга и кратковременная память: «У многих людей в голове растет дерево, но мозг сам по себе является больше травой [дерном], чем деревом.» Аксон и дендрит обвиваются один вокруг другого как въюнок вокруг колючего кустарника, имея по синапсу на каждой колючке [шипе]... кратковременная память также относится к типу ризомы, диаграммы, тогда как долговременная является древовидной и централизованной (отпечаток, инграмма [остаточное возбуждение нервной системы], калька или фотография) (Делез, Гваттари 1998).

Можно заметить, что ментальные процессы характеризуются как древовидностью, так и ризомностью, если первый тип характерен для абстрактно-логического мышления, то для начальных этапов развития мышления как в филогенезе ${ }^{2}$, так и в онтогенезе ${ }^{3}$ более характерен тип корешковый, ризомный. Характеристики ризомы характерны и для творческого, интуитивного типа мышления. Если абстрактно-логическое мышление характерно для формирования «истинных понятий» и установления между ними причинно-следственных и других логических связей, то интуитивное мышление подобно потоку неуправляемого, подверженного влиянию случайных внешних факторов сознанию, созданию необъяснимых связей, несовмести-

2 В качестве примера можно привести описанные в психолингвистике способы классификации детьми. В эксперименте Л. С. Сахарова детям предлагалось сложить в кучки деревянные геометрические фигурки, которые различались цветом, размером и формой и при этом имели названия. Маленькие и невысокие фигурки назывались квазисловом БАТ, маленькие и высокие - словом ДЕК, большие и высокие - МАП, а большие и невысокие - РОЦ. Далее исследователь брал в руки одну из фигурок, на которой было написано БАТ и предлагал детям угадать какие другие предметы называются так же. В процессе эксперимента ребенок получал обратную связь, на основании которой корректировал свои ответы. Полученные результаты показали, что дети при выделении групп фигурок проходят следующие фазы: а) обобщение по схеме «куча», т.е. обобщение по непонятному (или отсутствующему) признаку. Такое обобщение характерно для мышления ребенка до трех лет; б) обобщение по схеме «комплекс». Здесь уже можно усмотреть обобщающий признак, например яблоко и банан помещаются вместе, потому, что оба желтые, апельсин и яблоко потому, что круглые и т.д.; в) обобщение, обеспечивающее формирование истинных понятий, характерное для детей старшего возраста (цит. по: Фрумкина 2001: 116-118).

3 В некотором смысле похожей классификацией (по крайней мере по первым двум признакам) является классификация животных в «Китайской энциклопедии», которую цитирует Х. Борхес, ссылаясь на А. Куна: «Все животные делят на: а) принадлежащих Императору, б) набальзамированных, в) прирученных, г) молочных поросят, д) сирен, е) сказочных, ж) бродячих собак, 3) включённых в настоящую классификацию, и) бегающих как сумасшедшие, к) неисчисляемых, л) нарисованных тончайшей кистью из верблюжьей шерсти, м) и прочих, н) только что разбивших кувшин, о) похожих издали на мух...» (Борхес). 
мых с причинно-следственными отношениями, управляемых свободными ассоциациями и внешними случайными воздействиями (аттракторами). Этот процесс напоминающий создание порядка из хаоса, описанного И. Пригожиным и И. Стенгерс (Пригожин, Стенгерс 1986).

Естественный язык фиксирует процессы возникновения и развития значений слов, механизм которых подобен начальным формам детского, мифологического, а также интуитивного мышления. Углубляясь в анализ внутренней формы слов-первообразов и развития их значений, можно обнаружить характеристики ризомы, следующей неуправляемому логикой потоку мысли, неожиданным ассоциативным связям, «полетам на крохотном тельце метафоры». Вместе с тем, причудливая, хаотическая связь накапливаемых сем часто приводит к формированию нового значения, часто противоположного исходному. Сказанное действительно для обратного пути: бинарные структуры в свою очередь склонны разрастаться в ризому.

Так, в прецедентном библейском тексте о конфликте Каина и Авеля и убийстве Авеля Каином просматривается противопоставление цивилизация/культура - природа. Согласно Библейской энциклопедии, Авель - пастух, а Каин - земледелец (БЭБ URL). В библейской легенде Каин убивает Авеля из-за того, что его жертву Бог «не призрел», а «призрел» жертву Авеля. Объяснения предпочитания жертвенного ягненка плодам земледельческого труда Каина в Старом Завете нет. Наряду с известными версиями почему Господь «не призрел» жертву Каина можно полагать, что плод трудов Авеля (לקֶ? - первозданность, космос) был плодом труда, который не нарушал Природы, созданной Богом: Авель не преобразовывает ее в отличие от Каина (имя Каин предположительно происходит от каин - кузнец): для земледелия нужен металл, соответственно вмешательство в природу. Каин обрабатываem землю, именно от латинского слова colero (обрабатывать) и произошло слово культура. Показательно, что Каин (кузнец $\rightarrow$ культура, цивилизация) убивает Авеля (לרֶ? /хевел $\rightarrow$ первозданность, Природу). Эти рассуждения подкрепляются следующими фактами: Каин, будучи изгнан Богом, строит первый город. От потомков Каина - Тувалкаина (Каина из Тувала) и Иувала (Каина из Иувала) происходят все кузнецы и музыканты, которые создают искусственные, неприродные продукты, артефакты. Здесь следует отметить и связь архетипического кузнеца с музыкой и пением в ряде мифологий. Так, Вяч. Вс. Иванов и В. Н. Топоров отметили, что в русских народных сказках кузнец кует горло волку, а слагатели гимнов в Древней Индии назывались кави - одного корня с ковать, (Иванов, Топоров 1974: 65, 90). Эти факты позволяют интерпретировать противопоставление прецедентных имен Авель/ первозданность - Каин/кузнец как оппозицию природа (хевел/первозданность, космос - Авель) - культура, цивилизация (Каин/кузнец).

Характеристики ризомы можно наблюдать в связи прецедентного имени Каин, с одной стороны с архетипами кузнец и кузница, а с другой 
с концептом коварство. Связь Каина с кузнечеством прослеживается уже в этимологии его имени: Каин или Хаин значит кузнец (евр.qајіn от арамейского и арабского корня qjn - «ковать»; греч. Каin). Вместе с тем, другим семантическим рефлексом, кстати совмещенном с образом кузнеца

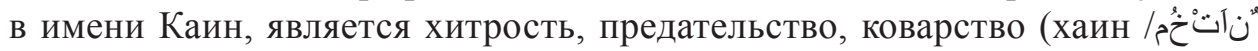
в арабском языке обозначает: предатель, лищемер). Из арабского слово перекочевало в турецкий язык, где hain обозначает хитреи, предатель. В Энциклопедии Кольера указываются и другие возможные пути происхождения имени Каин - от глагола kana - производить на свет, а также от слова kana - ревнивый (Энциклопедия Кольера). В качестве этимона названий города Кана или Канна Галилейская указывается тростник - из древнееврейского gnh ganah - тростник, земля тростника, т.е. земля, производящая тростник (Православие). С прецедентным именем Каин тростник связывается в некоторых апокрифических книгах. Так, в Житии Адама, рассказывается, что Каин, как только родился, сразу же вырос, побежал и принес камыш (тростник), именно поэтому его и назвали Каин. На первый взгляд, это различные, не связанные между собой гипотезы происхождения прецедентного имени. Но на самом деле, образ тростника/ камыша через сему «гибкость», связь с потусторонними силами связывает древнее слово коварство (как продукт деятельности кузнеца) и современное слово коварство (как козни, хитрость, вероломство, лукавство), а также саму сущность Каина, коварно убившего Авеля, причем продуктом деятельности кузнеца (коварством) - ножом. Камыш/тростник связан через сему «гибкость» со словами коварство, козни в прямом и в переносном смысле. В процессе ковки первоначальный материал - металл в результате разогрева становится пластичным, способным менять свою форму. Таким образом, коварство/козни, что первоначально означало продукт, полученный через обработку разогретого металла, имееющего свойство «пластичность», «гибкость» оказывается связанным через данную сему с тростником/камышом, а через него - с Каином. Поскольку образ кузнеца в большинстве мифологий связан с потусторонними силами, волшебством, слова козни и коварство приобрели значение «хитрость», «лукавство». Кузнецу приписывалась также связь с волшебством, магией, колдовством, поэтому продукт его деятельности стал обозначать не только артефакт, полученный в результате изменения формы, но и оценку, характеристику поведения человека, которая включает в себя семы «гибкость», «извилистость», что определялось и как лукавство (от «луко» - извилина, извилистый, срв. лукоморье). Сема «лукавство», «лукавость» (букв.: извилистость) также содержится в образе прецедентного героя Каина (букв.: кузнец). Каин, согласно апокрифам, считается сыном Евы и Сатаны (Лукавого-Змеи/Змея - гибкого, извилистого). Более того, известна связь самого мифического архетипического кузнеца со Змеем. Как и Змей, кузнец свя- 
зан с огнем, часто он безног или увечен (Баркова). Этимоном слова «плуг», которым Кузнец/Змей распахивает землю, является полоз (Змей), отсюда «позти», «ползать» (Фасмер). Продолжая идею связи тростника/камыша с Каином, мифическим кузнецом и продуктом его деятельности, можно отметить еще несколько значений, присущих этому символу. Тростник/ камыш является символом Ночи Духов. Кельты считали, что звук камышовой свирели открывает двери преисподней, а античные греки связывали тростник/камыш с огнем как жизненным началом (Прометей приносит огонь людям в полом тростнике/камыше). Так же, как кузнец, тростник/ камыш связывался с огнем и музыкой (Словарь символов).

Каждый из семантических рефлексов образует синонимические связи, или точнее, новые элементы ризомы. Среди синонимов слова коварство присутствует слово злокозненость, от слов зло и козни. Как сам кузнец, так и артефакты, созданные им, были окутаны дымкой загадочности, волшебства, что вызывало страх и недоверие, придавало ему самому и продуктам его труда зловещий ореол. В слове каверза также присутствуют общие семы извилистости, гибкости. Эти же семы прослеживаются в образе плетения, составляющего внутреннюю форму слова плутня, которые влекут за собой идею запутанности, сложности, головоломности. Каверзный, с точки зрения восприятия предполагает хитрость, коварство, хитроумие Другого, напряжение усилий для разгадывания истинной сущности. Происходит от прилагательного каверзный и существительного каверза, далее из приставки ка- (ко-) + *вьрз-; ср. верзти́ «вязать, плести», укр. ве́рзти «пустословить, молоть чепуху» (Фасмер). Крайний предел запутанности, невозможность проследить логику, непонятность это «нечто лишенное смысла»: верзти/вязать, плести чепуху, пустословить, суесловить. Впрочем, и метафора плетение, использованная в отношении литературного жанра плетение словес, включавшего приемы суггестии, изоколии и параллелизма, определенно имеет отношение к представлению об извилистости, запутанности высказывания, часто затемняющего основной коммуникативный посыл. Слово того же синонимического поля хитрый связано со словом кузнец и коварство/коварный через семы мудрый/сведущзий/сообразительный, а также ловкий/ опытный через такие качества кузнеца, как владение тайными знаниями, умение их использовать при достижении своих целей (Фасмер URL).

Рассматривая синонимы слов коварство/козни, можно заметить, что все они связаны через сему извилистость, гибкость, ведущую к образу Змея, символу коварства и возможному отцу Каина, согласно одному из апокрифов.

Все синонимы можно свести к одному из базовых концептов - концепту кривда, внутренняя форма которого также связана с семами гибкость, извилистость, изогнутость, нечто противоположное правде - прямому, пра- 
воте. Просматривается и другое сплетение ризомы, как бы втягивающее в себя общую сему - ту, которая характеризирует продукт работы кузнеца. Поскольку кузнец противостоит природе, продукт его деятельности это артефакт - тленное, суета, как и сам кузнец. К суете относятся и искусства, и прежде всего музыка, родоначальником которых является кузнец. В то же время суета восходит к библейскому хевел, которое вместе с тем означало также: первозданность, хаос и космос одновременно и, как было показано выше, имеет отношение к прецедентному имени Авель.

Как видно, возможные этимоны прецедентного имени Каин - кузнеи, тростник/камыши, Канна оказываются связанными через общие семы, а сами эти слова и их синонимы образуют связи и узлы, которые подобно побегам корневища - ризоме, получая подпитку за счет архетипов, либо прерывая эти связи, образуют новые под влиянием внешних аттракторов. Связи между этимонами не подчиняются структуре дерева: если Каин не был кузнецом, а первым кузнецом был Тувалкаин его потомок, то как он мог получить имя Каин (кузнец)? Вместе с тем Каин олицетворяет коварство, и содержит в себе много общего с тростником/камышом и Змеем... В данной ситуации невозможно задать вопрос «Откуда?» Сам Каин и все, что связано с ним, его функциями, качествами и функциями потомков это ситуация «и... и... и...», характерная для ризомы. Точно так же, как в ризоме, в которой нет ни начала, ни конца сплетение семантических рефлексов (побегов) прецедентного имени Каин представляет собой фрактал нового семантического узла (корешка) и образует новые побеги и связи...

В свою очередь семантические узлы (корешки) ризомы кривда и суета характеризуются своими этимонами и семантическими рефлексами ${ }^{4}$ и соответственно образуют новые «корешки» и связи...

\section{Библиография}

Библия. Книги Священного писания Ветхого и Нового Завета (1988), Издание Московской патриархии, Москва.

Иванов Вяч. Вс., Топоров В. Н. (1974), Исследования в области славянских древностей. Москва: Наука.

Пригожин И., Стенгерс И. (1986), Порядок из хаоса: Новый диалог человека с природой, пер. с англ., общ. ред. В. И. Аршинова, Ю. Л. Климонтовича и Ю. В. Сачкова, Москва: Прогресс.

Снегирев И. М. (1837), Русские народные праздники и суеверные обряды, Москва: Университетская типография.

Фрумкина Р. М. (2001), Психолингвистика, Москва.

\footnotetext{
${ }^{4}$ Нетрудно заметить, что ризома приобретает древовидность, а дерево - характеристики ризомы.
} 


\section{Интернет источники}

Баркова А. Л. Работы по общей мифологии, mith.ru〉Барковой〉smith.htm.

Библейская энциклопедия Брокгауза, http://www.agape-biblia.org/books/Book03.

Борхес X. Аналитический язык Джона Уилкинса, перевод Е. Лысенко, http://lib.ru/BORHES/ natroeniq.txt\#2.

Делез Ж., Гваттари (1994), Ф. Капитализм и иизофрения, http://tfk1.narod.ru/rizoma.htm.

Фасмер М. (1984), Этимологический словарь русского языка, http://fasmerbook.com.

Словарь символов, http://enc-dic.com/symbol.

Энциклопедия Кольера (1998), www.onlinedicx.ru/slovar/colier/k/kain_i_avel.html.

Православиеq www.pravoslavieto.com/poklonnichestvo/holy_land/kana.htm.

Tatyana Chalakova

\section{RHIZOME AS THE PRINCIPLE OF ORGANIZATION OF PRECEDENT PHENOMENA AND LINGUISTIC AND CULTURAL CONCEPTS}

(Summary)

The article discusses the possibility of describing semantic relations of words and their etymology on the example of the fragments that form a semantic field of precedent phenomenon Cain and linguistic-cultural concept of deceit through the rhizome. Rhizome is one of the ways of organization of complex systems, unstructured and nonlinear way, leaving open the possibility to realize their inner potential to self-configuring. The report illustrates that the rhizome serves as a model of unconscious mental processes, characterized by the absence of tree structure, and a model of semantic relations of words, their etymology and their semantic changes. The concept of rhizomes can be applied to the description of non-system differences, unable clearly opposed each to other by the presence or absence of any characteristic. By analogy with the process of interaction of abstract-logical and intuitive thinking linguistic rhizome is characterized with the flow of opposite structures.

Keywords: linguistic and culture, rhizome, concept, archetype, semantic reflex.

Татьяна Чалькова

\section{РИЗОМА КАК ПРИНЦИП ОРГАНИЗАЦИИ ПРЕЦЕДЕНТНЫХ ФЕНОМЕНОВ И ЛИНГВОКУЛЬТУРНЫХ КОНЦЕПТОВ}

(Резюме)

В статье рассматриваются возможности описания семантических связей слов и их этимологии на примере фрагментов, формирующих семантическое поле прецедентного имени Каин и лингвокультурного концепта коварство через понятие ризома. Ризома представляет 
собой один из способов организации сложных систем, некий внеструктурный и нелинейный способ, оставляющий открытой возможность для реализации их внутреннего потенциала самоконфигурирования. Показано, что ризома служит моделью бессознательных ментальных процессов, характеризующихся отсутствием древовидной структуры, а также моделью семантических связей слов, их этимологии и изменений их семантики. Понятие ризомы можно применить к описанию несистемных различий, неспособных четко противопоставляться друг другу по наличию или отсутствию какого-либо признака. По аналогии с процессом взаимодействия абстрактно-логического и интуитивного мышления для лингвистических ризом характерны перетекания оппозициональных структур.

Ключевые слова: лингвокультурология, ризома, конщепт, архетип, семантический рефлекс. 